NBER WORKING PAPER SERIES

\title{
EXCHANGE RATE DYNAMICS REDUX
}

\author{
Maurice Obstfeld \\ Kenneth Rogoff
}

Working Paper No. 4693

\section{NATIONAL BUREAU OF ECONOMIC RESEARCH \\ 1050 Massachusetts Avenue \\ Cambridge, MA 02138 \\ April 1994}

The authors thank the National Science Foundation and the German Marshall Fund of the United States for support. This paper is a part of the NBER's research program in International Finance and Macroeconomics. Any opinions expressed are those of the authors and not those of the National Bureau of Economic Research. 


\title{
EXCHANGE RATE DYNAMICS REDUX
}

\begin{abstract}
Until now, thinking on open economy macroeconomics has been largely schizophrenic. When it comes to analyzing exchange rate dynamics, an empirically-minded economist abandons modern current account models which, while theoretically coherent, fail to address the awkward reality of sticky nominal prices. In this paper we develop an analytically tractable two-country model that marries a full account of dynamics to a supply framework based on monopolistic competition and sticky prices. It offers simple and intuitive predictions about exchange rates and current accounts that sometimes differ sharply from those of either modern flexible-price intertemporal models, or traditional sticky-price Keynesian models. The model also leads to a novel perspective on the international welfare spillovers of monetary and fiscal policies.
\end{abstract}

Maurice Obstfeld

Department of Economics

University of California, Berkeley

787 Evans Hall

Berkeley, CA 94720

and NBER
Kenneth Rogoff

Woodrow Wilson School

416 Robertson Hall

Princeton University

Princeton, NJ 08544-1013

and NBER 


\section{Introduction}

This paper offers a theory that incorporates the price rigidities essential to explain exchange-rate behavior without sacrificing the insights of the intertemporal approach to the current account. Until now, thinking on open-economy macroeconomics has been largely schizophrenic. Most of the theoretical advances since the late 1970s have been achieved by assuming away the awkward reality of sticky prices and instead developing the implications of dynamic optimization by the private sector. While the intertemporal approach has proved valuable for some facets of current-account analysis, many of the most fundamental problems in international finance cannot be seriously addressed in a setting of frictionless markets. Because the newer paradigm seems so ill-equipped to explain, for example, the effects of macroeconomic policies on output and exchange rates, empirical practitioners and policymakers have not yet been persuaded to abandon traditional aggregative Keynesian models.

While the time-tested appeal of these models is undeniable, their lack of microfoundations presents problems at many levels. They ignore the intertemporal budget constraints central to any coherent picture of the current account and fiscal policy. They provide no clear description of how monetary policy affects production decisions. Because it embodies no meaningful welfare criteria, the traditional approach can yield profoundly misleading policy prescriptions even for problems it was designed to address-as we shall show.

This paper builds a bridge between the rigor of the intertemporal approach, as exemplified by Sachs (1981), Obstfeld (1982), and Frenkel and Razin (1987), and the descriptive plausibility of the classic contributions by Fleming (1962), Mundell (1963, 1964), and Dornbusch (1976). We develop a model of international policy transmission that embodies all the central elements of the intertemporal approach along with short-run nominal price rigidities and explicit microfoundations of aggregate supply.

A framework integrating exchange rate dynamics and the current account yields a new perspective on both. In contrast to overshooting models based on Dornbusch (1976), monetary shocks have permanent effects on consumption, output, and the terms of trade. If money affects output in the short run, it generally induces current-account imbalances. The resulting international wealth transfer produces real effects that last well beyond the horizon over which prices are rigid. Many of the model's predictions stem from the result that money demand depends on consumption, which typically can be 
smoothed over time more easily in open than in closed economies. ${ }^{1}$ For example, even temporary fiscal innovations induce random walks in nominal exchange rates. ${ }^{2}$ In contrast to flexible-price intertemporal models such as those in Frenkel and Razin (1987), a permanent tax-financed increase in domestic government spending produces a home current-account surplus and a decline in the world real interest rate. In a flexible-price representative-agent model, neither variable would change. But under sticky prices, a permanent rise in government demand raises output and saving in the short run.

Our model embeds features of the static, closed-economy models of Blanchard and Kiyotaki (1987) and Ball and Romer (1989) in an analytically tractable, dynamic, two-country framework. Section 2 sets out an infinitehorizon monetary model of a monopolistically competitive world economy. We show how to solve for the long-run and short-run equilibria of a loglinearized version of the model. In section 3 we analyze positive and normative aspects of monetary and fiscal policy. Section 4 concludes by evaluating the model's implications for a range of questions in international finance.

Various elements of our approach can be found in earlier work by several authors. Each component of Mussa's (1984) aggregative model is inspired by individual maximization, but the model as a whole lacks an integrative foundation. McKibbin and Sachs (1991) and Stockman and Ohanian (1993) develop numerical sticky-price models that incorporate intertemporal maximization but lack foundations on the supply side. The model of Calvo and Végh (1993) assumes sticky wages and demand-determined output, but presents no rationale for the latter assumption. Also, its smallcountry assumption prevents analysis of international transmission issues. Romer (1993) models a world of two interacting monopolistically competitive economies, but his analysis is static and its microfoundations are not fully specified. Perhaps the closest precursor to our study is Svensson and van Wijnbergen (1989); but its assumption of perfectly pooled international risks, aside from matching uneasily its pricing and rationing assumptions, precludes discussion of the current-account movements and fiscal shocks that are central to our analysis.

\footnotetext{
${ }^{1} \mathrm{~A}$ role for consumption spending rather than output in United States money demand receives empirical support from Mankiw and Summers (1986).

${ }^{2}$ Rogoff (1992) presents a model in which transitory productivity and government spending shocks can have long-lasting effects on the real exchange rate due to traded goods consumption smoothing.
} 


\section{Macroeconomic Policies in a Two-Country Model with Monopolistic Competition: Flex- ible Prices}

In this section we describe the setup of the model and some of its properties when nominal output prices are flexible.

\subsection{Preferences, technology, and market structure}

The world is inhabited by a continuum of individual producers, indexed by $z \in[0,1]$, each of whom produces a single differentiated perishable product. The home country consists of producers on the interval $[0, n]$, while the remaining $(n, 1]$ producers reside in the foreign country.

Individuals everywhere in the world have the same preferences, which are defined over a consumption index, real money balances, and effort expended in production. Let $c(z)$ be a home individual's consumption of product $z$. The consumption index, on which utility depends, is given by

$$
C=\left[\int_{0}^{1} c(z)^{\frac{\theta-1}{\theta}} d z\right]^{\frac{\theta}{\theta-1}}
$$

where $\theta>1$. The foreign consumption index $C^{*}$ is defined analogously, where, throughout, stars denote foreign variables.

There are no impediments or costs to trade between the countries. Let $E$ be the nominal exchange rate, defined as the home-currency price of foreign currency, $p(z)$ the domestic-currency price of $\operatorname{good} z$, and $p^{*}(z)$ the price of the same good in foreign currency. Then the law of one price holds for every good, so that

$$
p(z)=E p^{*}(z)
$$

The consumption-based money price index ${ }^{3}$ in the home country is

$$
P=\left[\int_{0}^{1} p(z)^{1-\theta} d z\right]^{\frac{1}{1-\theta}}=\left[\int_{0}^{n} p(z)^{1-\theta} d z+\int_{n}^{1} E p^{*}(z)^{1-\theta} d z\right]^{\frac{1}{1-\theta}}
$$

${ }^{3}$ The price index is defined as the minimal expenditure of domestic money needed to purchase a unit of $C$. 
Since both countries' residents have the same preferences, eq. (2) implies that

$$
P=E P^{*}
$$

There is an integrated world capital market in which both countries can borrow and lend. The asset they trade is a real bond, denominated in the composite consumption good. Let $r_{t}$ denote the real interest rate earned on bonds between dates $t$ and $t+1$, while $F_{t}$ and $M_{t}$ are the stocks of bonds and domestic money held by a home resident entering date $t+1$. Residents of a country derive utility from that country's currency only, and not from foreign currency. Individual $z$ 's period budget constraint therefore is

$$
P_{t} F_{t}+M_{t}=P_{t}\left(1+r_{t-1}\right) F_{t-1}+M_{t-1}+p_{t}(z) y_{t}(z)-P_{t} C_{t}-P_{t} T_{t}
$$

where $y(z)$ is the individual's output and $T$ denotes real taxes paid to the domestic government (which can be negative in the event of money transfers).

A home resident $z$ maximizes a utility function that depends positively on consumption and real balances, and negatively on work effort, which is positively related to output:

$$
U_{t}=\sum_{s=t}^{\infty} \beta^{s-t}\left[\frac{\sigma}{\sigma-1} C_{s}^{\frac{\sigma-1}{\sigma}}+\frac{\chi}{1-\varepsilon}\left(\frac{M_{s}}{P_{s}}\right)^{1-\varepsilon}-\frac{\kappa}{\mu} y_{s}(z)^{\mu}\right]
$$

Above, $0<\beta<1, \mu>1$, and $\sigma, \varepsilon>0$.

Given the utility function (6), a home individual's demand for product $z$ in period $t$ is

$$
c_{t}(z)=\left[\frac{p_{t}(z)}{P_{t}}\right]^{-\theta} C_{t}
$$

so that $\theta$ is the elasticity of demand with respect to relative price. Foreign residents have the same demand functions.

We assume that home and foreign government consumptions do not directly affect private utility. Per capita real home government consumption expenditure, $G$, is a composite of government consumptions of individual goods, $g(z)$, in the same manner as private consumption; for simplicity, we assume identical weights. ${ }^{4}$ The same is true for $G^{*}$. Since Ricardian

${ }^{4}$ That is,

$$
G=\left[\int_{0}^{1} g(z)^{\frac{0-1}{\rho}} d z\right]^{\frac{0}{-1}}
$$


equivalence holds in this model, nothing is lost by simply assuming that all government spending is financed by taxes and seignorage

$$
G_{t}=T_{t}+\frac{M_{t}-M_{t-1}}{P_{t}}, \quad G_{t}^{*}=T_{t}^{*}+\frac{M_{t}^{*}-M_{t-1}^{*}}{P_{t}^{*}}
$$

Governments take producer prices as given when allocating their purchases among goods. Adding up private and government demands therefore shows that the producer of good $z$ faces the period $t$ world demand curve:

$$
y_{t}^{d}(z)=\left[\frac{p_{t}(z)}{P_{t}}\right]^{-\theta}\left[Q_{t}+n G_{t}+(1-n) G_{t}^{*}\right]
$$

where

$$
\mathbf{Q}_{t} \equiv n C_{t}+(1-n) C_{t}^{*}
$$

is total private world consumption demand. Eq. (8) makes use of (2) and (4), which imply that the real price of good $z$ is the same at home and abroad.

Each individual producer has a degree of monopoly power. Thus, in the aggregate, a country faces a downward-sloping world demand curve for its output, as in Dornbusch (1976). Purchasing power parity holds for consumer price indexes [eq. (4)] because both countries consume identical commodity baskets, but it does not hold for national output deflators and the terms of trade can change. ${ }^{5}$

\subsection{Individual maximization}

Use (8) to eliminate $p_{t}(z)$ from (5), ${ }^{6}$ then maximize lifetime utility (6) subject to the resulting budget constraint, taking $Q_{t}$ as given. Define the homecurrency nominal interest rate on date $t, i_{t}$, by

$$
1+i_{t}=\frac{P_{t+1}}{P_{t}}\left(1+r_{t}\right)
$$

The model can be extended to give the government a preference for home goods, but the case in the text is notationally simpler.

${ }^{5}$ In an extended version of the model incorporating nontraded goods, many of the basic results derived below still follow despite the fact that eq. (4) need no longer hold.

${ }^{6}$ The substitution yields

$$
p_{t}(z) y_{t}(z)=P_{t} y_{t}(z)^{\frac{0-1}{\zeta}}\left[Q_{t}+n G_{t}+(1-n) G_{t}^{*}\right]^{\frac{1}{d}}
$$


with an analogous definition for the foreign-currency nominal interest rate. Note that since purchasing power parity holds, real interest rate equality implies uncovered interest parity: $1+i_{t}=\frac{E_{t+1}}{E_{t}}\left(1+i_{t}^{*}\right)$.

The first-order conditions for the maximization problems of home and foreign individuals are:

$$
\begin{gathered}
C_{t+1}=\beta^{\sigma}\left(1+r_{t}\right)^{\sigma} C_{t} \\
C_{t+1}^{*}=\beta^{\sigma}\left(1+r_{t}\right)^{\sigma} C_{t}^{*} \\
\frac{\chi\left(M_{t} / P_{t}\right)^{-\epsilon}}{C_{t}^{-1 / \sigma}}=\frac{i_{t}}{1+i_{t}} \\
\frac{\chi\left(M_{t}^{*} / P_{t}^{*}\right)^{-\epsilon}}{C_{t}^{*-1 / \sigma}}=\frac{i_{t}^{*}}{1+i_{t}^{*}} \\
y_{t}(z)^{\mu-1+(1 / \theta)}=\left(\frac{\theta-1}{\theta \kappa}\right) C_{t}^{-1 / \sigma}\left[Q_{t}+n G_{t}+(1-n) G_{t}^{*}\right]^{1 / \theta} \\
y_{t}^{*}(z)^{\mu-1+(1 / \theta)}=\left(\frac{\theta-1}{\theta \kappa}\right) C_{t}^{*-1 / \sigma}\left[Q_{t}+n G_{t}+(1-n) G_{t}^{*}\right]^{1 / \theta}
\end{gathered}
$$

Eqs. (11) and (12) are standard consumption Euler equations. The moneymarket equilibrium conditions (13) and (14) equate the marginal rate of substitution of composite consumption for the services of real money balances to the consumption opportunity cost of holding real balances. Notice that money demand depends on consumption rather than income, a distinction that can be even more important in open than in closed economies. ${ }^{7}$ Eqs. (15) and (16) state that the marginal utility of the higher revenue earned from producing an extra unit of good $z$ equals the marginal disutility of the needed effort.

\subsection{A symmetric steady state}

In a steady state all exogenous variables are constant. ${ }^{8}$ Since this implies that consumption is constant, the world real interest rate $r$ is tied down by

\footnotetext{
${ }^{7}$ In a model with firm and government holdings of transactions balances, a broader expenditure measure would be appropriate for analyzing money demand.

${ }^{8}$ It is simple to allow for steady-state growth in the money supplies and other exogenous variables.
} 
the consumption Euler conditions (11) and (12):

$$
r=\frac{1-\beta}{\beta}
$$

All producers in a country are symmetric, which implies that they set the same price and output in equilibrium. Let $p(h)$ be the home-currency price of a typical home good and $p^{*}(f)$ the foreign-currency price of a typical foreign good; $y$ and $y^{*}$ are the corresponding output levels. If composite consumption is constant in both countries, then each country's intertemporal budget constraint requires that real consumption spending be equal to net real interest payments from abroad plus real domestic output less real government spending. ${ }^{9}$ Thus, steady-state per capita consumption levels are:

$$
\begin{gathered}
C=r F+\frac{p(h) y}{P}-G \\
C^{*}=-r\left(\frac{n}{1-n}\right) F+\frac{p^{*}(f) y^{*}}{P^{*}}-G^{*}
\end{gathered}
$$

(Notice that eq. (19) makes use of the identity $n F+(1-n) F^{*}=0$ : world net foreign assets must be zero.) We stress again that even though people in different countries face the same relative price for any given good, the relative price of home and foreign goods (the terms of trade) can vary. Even the steady-state terms of trade change as relative wealth changes because the marginal benefit from production is declining in wealth.

In the special case where net foreign assets are zero and per capita government spending levels are equal, there is a closed-form solution for the steady state, in which the countries have identical per capita outputs and real money holdings. We shall denote by zero subscripts the particular steady state with both $F_{0}=F_{0}^{*}=0$ and $G_{0}=G_{0}^{*}=0$; in it,

$$
\begin{gathered}
y_{0}=y_{0}^{*}=\left(\frac{\theta-1}{\theta \kappa}\right)^{\frac{\sigma}{\sigma(\mu-1)+1}} \\
\frac{M_{0}}{P_{0}}=\frac{M_{0}^{*}}{P_{0}^{*}}=\left(\frac{1-\beta}{\chi}\right)^{\frac{1}{c}} y_{0}^{-\frac{1}{\sigma \epsilon}}
\end{gathered}
$$

${ }^{9} \mathrm{It}$ is at this point that we are imposing the countries' intertemporal budget constraints, which rule out Ponzi schemes of unlimited borrowing. 
Eq. (20) is identical to the output equation in the static closed-economy model of Blanchard and Kiyotaki (1987): producers' market power pushes global output below its competitive level, which is approached only as $\theta \rightarrow$ $\infty$. Because this model is dynamic, real money balances in general depend on nominal interest rates. We have assumed a zero-inflation steady-state, so this effect shows up in (21) only as an effect of the steady-state value of $\frac{r}{1+r}=1-\beta$.

\subsection{A log-linearized model}

To go further and allow for asymmetries in policies and current accounts, it is helpful to log-linearize the model around the initial symmetric steady state with $F_{0}=F_{0}^{*}=0$ and $G_{0}=G_{0}^{*}=0$. We implement this linearization by expressing the model in terms of deviations from the baseline steady-state path. Denote percentage changes from the baseline by hats; thus, for any variable, $\hat{X} \equiv d X / X_{0}$, where $X_{0}$ is the initial steady-state value.

The easiest equation to start with is the purchasing power parity relation (4), which requires no approximation:

$$
\hat{E}_{t}=\hat{P}_{t}-\hat{P}_{t}^{*}
$$

Given the symmetry among each country's producers, eq. (3) yields

$$
\begin{aligned}
P_{t} & =\left\{n p_{t}(h)^{1-\theta}+(1-n)\left[E_{t} p_{t}^{*}(f)\right]^{1-\theta}\right\}^{\frac{1}{1-\theta}} \\
P_{t}^{*} & =\left\{n\left[p_{t}(h) / E_{t}\right]^{1-\theta}+(1-n) p_{t}^{*}(f)^{1-\theta}\right\}^{\frac{1}{1-\theta}}
\end{aligned}
$$

Small percentage deviations of consumer price levels from their initial paths thus are given by

$$
\begin{gathered}
\hat{P}_{t}=n \hat{p}_{t}(h)+(1-n)\left[\hat{E}_{t}+\hat{p}_{t}^{*}(f)\right] \\
\hat{P}_{t}^{*}=n\left[\hat{p}_{t}(h)-\hat{E}_{t}\right]+(1-n)\left[\hat{p}_{t}^{*}(f)\right]
\end{gathered}
$$

where we have used the fact that at the initial symmetric steady state, $p_{0}(h)=E_{0} p_{0}^{*}(f)$. 
Next, take a population-weighted average of (5) and its foreign counterpart. Combining the result with (7) and (9) gives the global goods-market equilibrium condition:

$$
\mathbf{Q}_{t}=n\left[\frac{p_{t}(h) y_{t}}{P_{t}}-G_{t}\right]+(1-n)\left[\frac{p_{t}^{*}(f) y_{t}^{*}}{P_{t}^{*}}-G_{t}^{*}\right]
$$

Thus, linearizing implies that the change in world private demand is

$$
\begin{gathered}
\hat{\mathbf{Q}}_{t}=n \hat{C}_{t}+(1-n) \hat{C}_{t}^{*} \\
=n\left[\hat{p}_{t}(h)+\hat{y}_{t}-\hat{P}_{t}-\frac{d G_{t}}{\mathbf{Q}_{0}}\right]+(1-n)\left[\hat{p}_{t}^{*}(f)+\hat{y}_{t}^{*}-\hat{P}_{t}^{*}-\frac{d G_{t}^{*}}{\mathbf{Q}_{0}}\right]
\end{gathered}
$$

Remember that in the initial symmetric steady state, $p_{0}(h)=P_{0}$ and $p_{0}^{*}(f)=$ $P_{0}^{*}$. Remember also that because world population is normalized at 1 and initial net foreign assets and government consumptions are zero, $\mathbf{Q}_{0}=C_{0}=$ $C_{0}^{*}=y_{0}=y_{0}^{*}$.

The log-linearized versions of (8) and its foreign counterpart, interpreted as world demand schedules for typical domestic and foreign products, are

$$
\begin{aligned}
& \hat{y}_{t}=\theta\left[\hat{P}_{t}-\hat{p}_{t}(h)\right]+\hat{\mathbf{Q}}_{t}+n \frac{d G_{t}}{\mathbf{Q}_{0}}+(1-n) \frac{d G_{t}^{*}}{\mathbf{Q}_{0}} \\
& \hat{y}_{t}^{*}=\theta\left[\hat{P}_{t}^{*}-\hat{p}_{t}^{*}(f)\right]+\hat{\mathbf{Q}}_{t}+n \frac{d G_{t}}{\mathbf{Q}_{0}}+(1-n) \frac{d G_{t}^{*}}{\mathbf{Q}_{0}}
\end{aligned}
$$

Eqs. (15) and (16), which describe the optimal flexible-price output levels, are approximated by

$$
\begin{aligned}
& \left(\mu-1+\frac{1}{\theta}\right) \hat{y}_{t}=-\frac{1}{\sigma} \hat{C}_{t}+\frac{1}{\theta}\left[\hat{\mathbf{Q}}_{t}+n \frac{d G_{t}}{\mathbf{Q}_{0}}+(1-n) \frac{d G_{t}^{*}}{\mathbf{Q}_{0}}\right] \\
& \left(\mu-1+\frac{1}{\theta}\right) \hat{y}_{t}^{*}=-\frac{1}{\sigma} \hat{C}_{t}^{*}+\frac{1}{\theta}\left[\hat{\mathbf{Q}}_{t}+n \frac{d G_{t}}{\mathbf{Q}_{0}}+(1-n) \frac{d G_{t}^{*}}{\mathbf{Q}_{0}}\right]
\end{aligned}
$$

The consumption Euler eqs. (11) and (12) take the log-linear form

$$
\begin{aligned}
& \hat{C}_{t+1}=\hat{C}_{t}+\sigma(1-\beta) \hat{r}_{t} \\
& \hat{C}_{t+1}^{*}=\hat{C}_{t}^{*}+\sigma(1-\beta) \hat{r}_{t}
\end{aligned}
$$


near the initial steady-state path. Finally, the money-demand eqs. (13) and (14) become

$$
\begin{aligned}
\hat{M}_{t}-\hat{P}_{t} & =\frac{1}{\sigma \varepsilon} \hat{C}_{t}-\frac{\beta}{\varepsilon}\left(\hat{r}_{t}+\frac{\hat{P}_{t+1}-\hat{P}_{t}}{1-\beta}\right) \\
\hat{M}_{t}^{*}-\hat{P}_{t}^{*} & =\frac{1}{\sigma \varepsilon} \hat{C}_{t}^{*}-\frac{\beta}{\varepsilon}\left(\hat{r}_{t}+\frac{\hat{P}_{t+1}^{*}-\hat{P}_{t}^{*}}{1-\beta}\right)
\end{aligned}
$$

\subsection{Comparing steady states}

To solve the model, we still need the intertemporal budget constraints, which are implicit in eqs. (18) and (19) when the exogenous variables are constant. Linearizing these two equations, and letting primed hatted variables denote percent changes in steady state values, yields

$$
\begin{gathered}
\hat{C}^{\prime}=\left(\frac{1-\beta}{\beta}\right) \frac{d F^{\prime}}{\mathbf{Q}_{0}}+\hat{p}(h)^{\prime}+\hat{y}^{\prime}-\hat{P}^{\prime}-\frac{d G^{\prime}}{\mathbf{Q}_{0}} \\
\hat{C}^{* \prime}=-\left(\frac{1-\beta}{\beta}\right)\left(\frac{n}{1-n}\right) \frac{d F^{\prime}}{\mathbf{Q}_{0}}+\hat{p}^{*}(f)^{\prime}+\hat{y}^{* \prime}-\hat{P}^{* \prime}-\frac{d G^{* \prime}}{\mathbf{Q}_{0}}
\end{gathered}
$$

where (17) has been used to substitute for $r$.

The final step in solving for the steady state is to observe that eqs. (26)-(30) hold across steady states, so that they remain valid after timesubscripted changes are replaced by 'primed' changes. Together with (35) and $(36)$, they furnish seven equations in the seven unknowns, $\hat{C}^{\prime}, \hat{C}^{* \prime}, \hat{y}^{\prime}$, $\hat{y}^{* \prime}, \hat{p}(h)^{\prime}-\hat{P}^{\prime}, \hat{p}^{*}(f)^{\prime}-\hat{P}^{* \prime}$, and $\hat{\mathbf{Q}}^{\prime}$, which we can use to determine the new real steady state. The solutions for consumption are:

$$
\begin{gathered}
\hat{C}^{\prime}=\frac{\mathrm{A}}{\Delta}\left(\frac{r d F^{\prime}}{\mathrm{Q}_{0}}\right)+\frac{\mathrm{B}}{\Delta}\left[(1-n) \frac{d G^{* \prime}}{\mathrm{Q}_{0}}\right]-\frac{\Gamma}{\Delta}\left(\frac{d G^{\prime}}{\mathrm{Q}_{0}}\right) \\
\hat{C}^{* \prime}=-\frac{\mathrm{A}}{\Delta}\left(\frac{n}{1-n}\right) \frac{r d F^{\prime}}{\mathrm{Q}_{0}}+\frac{\mathrm{B}}{\Delta}\left(n \frac{d G^{\prime}}{\mathrm{Q}_{0}}\right)-\frac{\Gamma^{*}}{\Delta}\left(\frac{d G^{* \prime}}{\mathrm{Q}_{0}}\right)
\end{gathered}
$$

where

$$
\begin{gathered}
\mathrm{A} \equiv \sigma[1+\theta(\mu-1)] \\
\mathrm{B} \equiv \frac{\sigma \mu}{1+\sigma(\mu-1)}
\end{gathered}
$$




$$
\begin{gathered}
\Gamma \equiv \sigma(\theta-1)(\mu-1)+\sigma \mu\left[1-\frac{n}{1+\sigma(\mu-1)}\right] \\
\Gamma^{*} \equiv \sigma(\theta-1)(\mu-1)+\sigma \mu\left[1-\frac{1-n}{1+\sigma(\mu-1)}\right] \\
\Delta \equiv \mathrm{A}+\theta-1
\end{gathered}
$$

Consider eq. (37) for home private consumption. An exogenous increase $d F^{\prime}$ in home per capita foreign assets would increase steady-state consumption by the amount $r d F^{\prime}$ were output exogenous. Instead, consumption increases here by less (since $\mathrm{A} / \Delta<1$ ). The reason is that higher wealth leads to some reduction in work effort and production: as (29) shows, higher consumption lowers the marginal utility of consumption and, thus, marginal revenue measured in utility units. Notice that as $\sigma \rightarrow \infty$ (making the marginal utility of consumption insensitive to its level),$A / \Delta \rightarrow 1$. We also see from (37) that a steady-state rise in foreign government consumption increases domestic private consumption because part of the spending falls on domestic output, which rises in response. When steady-state home government consumption rises, however, home private consumption falls. There is a positive effect on output, as we explain in a moment, but it is more than offset by a higher domestic tax burden. Positive output effects do, however, allow private consumptions to fall by less than the associated tax increases (notice that $\Gamma / \Delta$ and $\Gamma^{*} / \Delta$ in (37) and (38) are both less than 1).

To see the effects of net foreign assets and fiscal policies on outputs and the terms of trade, observe that (27)-(30) and purchasing power parity (22) imply:

$$
\begin{gathered}
\hat{y}^{\prime}=-\frac{\theta}{\mathrm{A}} \hat{C}^{\prime}+\frac{1}{\mathrm{~A}[1+\sigma(\mu-1)]}\left[n \frac{d G^{\prime}}{\mathbf{Q}_{0}}+(1-n) \frac{d G^{* \prime}}{\mathbf{Q}_{0}}\right] \\
\hat{y}^{* \prime}=-\frac{\theta}{\mathrm{A}} \hat{C}^{* \prime}+\frac{1}{\mathrm{~A}[1+\sigma(\mu-1)]}\left[n \frac{d G^{\prime}}{\mathbf{Q}_{0}}+(1-n) \frac{d G^{* \prime}}{\mathbf{Q}_{0}}\right] \\
\hat{p}(h)^{\prime}-\hat{p}^{*}(f)^{\prime}-\hat{E}^{\prime}=\frac{1}{\theta}\left(\hat{y}^{* \prime}-\hat{y}^{\prime}\right)=\frac{1}{\mathrm{~A}}\left(\hat{C}^{\prime}-\hat{C}^{* \prime}\right)
\end{gathered}
$$

The first two equations above show the multiplier effects of domestic government spending on output emphasized by Mankiw (1987) and Startz (1989). Higher taxes makes producers work harder (this would be true under perfect competition as well); the resulting net stimulus to aggregate demand reinforces this output effect under monopolistic competition. Eq. (46) shows 
that the increase in the domestic terms of trade (the rise in the relative price of home products) is proportional to both the increase in relative foreign output and the increase in relative domestic consumption. ${ }^{10}$ Note that because the infinitely-lived citizens in both countries have equal constant discount rates, an international transfer of assets leads to permanent change in the terms of trade. ${ }^{11}$

With flexible prices, the classical invariance of the real economy with respect to monetary factors holds in this model. Across steady states inflation and the interest rate don't change, so (33) and (34) imply that

$$
\begin{gathered}
\hat{P}^{\prime}=\hat{M}^{\prime}-\frac{1}{\sigma \varepsilon} \hat{C}^{\prime} \\
\hat{P}^{* \prime}=\hat{M}^{* \prime}-\frac{1}{\sigma \varepsilon} \hat{C}^{* \prime}
\end{gathered}
$$

\section{The Two-Country Model with Sticky Prices}

We are now ready to understand the short-run behavior of exchange rates, the current account, and other key variables. In the short run, nominal producer prices $p(h)$ and $p^{*}(f)$ are predetermined; that is, they are set a period in advance but can be adjusted fully after one period. We will not explicitly model the underlying source of stickiness here-though one could, in principle, extend the analysis to incorporate small menu costs of price adjustment à la Akerlof and Yellen (1985a,b), Mankiw (1985), or Blanchard and Kiyotaki (1987). ${ }^{12}$

${ }^{10}$ This proportionality follows from the specific types of shocks assumed, and does not hold in general. Permanent productivity shocks, which we mention later, would cause a negative correlation between a country's terms of trade and its consumption. National bias in government spending also would modify the simple proportionality in (46).

${ }^{11}$ In other types of model-for example in an overlapping generations model-a transfer of assets has only temporary effects since the generations that receive the transfer eventually die out.

${ }^{12}$ One can potentially extend this model to incorporate richer price dynamics, for example, staggered price setting. Pricing to market issues (e.g., Dornbusch 1987 and Krugman 1987) do not arise here because there are no impediments to trade. 


\subsection{Short-run equilibrium conditions}

With preset nominal prices, output becomes demand determined for small enough shocks. Because a monopolist always prices above marginal cost, it is profitable to meet unexpected demand at the preset price. ${ }^{13}$ In the short run, therefore, the equations equating marginal revenue and marginal cost in the flexible-price case, (29) and (30), need not hold. Instead, output is determined entirely by the demand equations, (27) and (28).

Although prices are preset in terms of the producers' own currencies, the foreign-currency price of a producer's output must change if the exchange rate moves. How do exchange-rate changes affect relative prices and demands in the short run? With rigid output prices, eqs. (23) and (24) imply

$$
\begin{gathered}
\hat{P}=(1-n) \hat{E} \\
\hat{P}^{*}=-n \hat{E}
\end{gathered}
$$

In (49) and (50), and henceforth, we use hatted 'unprimed' variables to denote short-run deviations from the symmetric steady-state path. Combining these price changes with (27) and (28) shows that short-run aggregate demands can be expressed as

$$
\begin{gathered}
\hat{y}=\theta(1-n) \hat{E}+\hat{\mathbf{Q}}+n \frac{d G}{\mathrm{Q}_{0}}+(1-n) \frac{d G^{*}}{\mathrm{Q}_{0}} \\
\hat{y}^{*}=-\theta n \hat{E}+\hat{\mathbf{Q}}+n \frac{d G}{\mathrm{Q}_{0}}+(1-n) \frac{d G^{*}}{\mathrm{Q}_{0}}
\end{gathered}
$$

where $\hat{\mathbf{Q}}$ is given by (26). The remaining equations of short-run equilibrium include (31)-(34), which always hold.

In the specific policy experiments we do, where we consider one-period (temporary) or permanent changes from the baseline policies, the world economy reaches its new steady state after a single period. ${ }^{14}$ Thus, we can replace all $(t+1)$-subscripted variables in the consumption Euler and money

${ }^{13}$ It would be more profitable still to raise the price if this were possible in the short run. If there is an unexpected fall in demand and the monopolist cannot cut price, there is no choice but to produce and sell less.

${ }^{14}$ With more general assumptions on the exogenous variables, the economy would reach a possibly moving flexible-price equilibrium after one period absent further shocks. 
demand eqs. (31)-(34) with the 'primed' hatted variables indicating steadystate changes. All $t$-subscripted variables are interpreted as short-run values.

In the last section, we solved for the new steady state as a function of the permanent changes in money supplies and government spending, as well as the change in net foreign assets (the current account). The change in net foreign assets, however, is endogenous and can be determined only in conjunction with a full solution of the model's intertemporal equilibrium.

In the long run here, current accounts are balanced, as implied by the steady-state conditions (18) and (19). In the short run, however, the home country's per capita current account surplus is given by

$$
F_{t}-F_{t-1}=r_{t-1} F_{t-1}+\frac{p_{t}(h) y_{t}}{P_{t}}-C_{t}-G_{t}
$$

and similarly for the foreign country. Thus, since $F_{0}=0$, the linearized short-run current account equations are given by

$$
\begin{gathered}
\frac{d F^{\prime}}{\mathrm{Q}_{0}}=\hat{y}-\hat{C}-(1-n) \hat{E}-\frac{d G}{\mathrm{Q}_{0}} \\
\frac{d F^{* \prime}}{\mathrm{Q}_{0}}=\hat{y}^{*}-\hat{C}^{*}+n \hat{E}-\frac{d G^{*}}{\mathrm{Q}_{0}}=-\left(\frac{n}{1-n}\right) \frac{d F^{\prime}}{\mathrm{Q}_{0}}
\end{gathered}
$$

where we have made use of (49) and (50). Note that the primed variables $d F^{\prime}$ and $d F^{* \prime}$ appear above because the asset stocks at the end of period $t$ are steady-state levels.

\subsection{Solution of the model: money shocks}

One can formally solve the model in two stages. The first stage, already dealt with in section 2.5 , is to solve for all the steady-state (primed) variables as functions of the steady state macroeconomic policy shifts and the first period current account, $d F^{\prime}$. Ten short-run variables remain to be determined: $\hat{C}, \hat{C}^{*}, \hat{y}, \hat{y}^{*}, \hat{P}, \hat{P}^{*}, \hat{E}, \hat{\mathbf{Q}}, \hat{r}$, and $d F^{\prime}$. The ten equations that jointly determine them are (26), (31)-(34), and (49)-(53). Though a direct solution is possible, we prefer an intuitive approach that exploits the model's symmetry.

We simplify by looking at monetary and fiscal shocks separately, taking the former first and thus assuming temporarily that $d G=d G^{\prime}=d G^{*}=$ $d G^{* \prime}=0$. Nothing is lost by taking this approach, since the effects are additive. 


\subsubsection{Exchange rate dynamics}

Some of the model's main predictions can be seen by looking at international differences in macroeconomic variables. Subtracting the foreign Euler eq. (32) from its home counterpart (31) gives

$$
\hat{C}-\hat{C}^{*}=\hat{C}^{\prime}-\hat{C}^{* \prime}
$$

A similar operation on the money-demand eqs. (34) and (33) leads to

$$
\left(\hat{M}-\hat{M}^{*}\right)-\hat{E}=\frac{1}{\sigma \varepsilon}\left(\hat{C}-\hat{C}^{*}\right)-\frac{\beta}{(1-\beta) \varepsilon}\left(\hat{E}^{\prime}-\hat{E}\right)
$$

after using (22), which holds in the short and long runs alike.

Eq. (55) states that shocks have permanent effects on the difference between home and foreign per capita consumption. Individuals need not have flat consumption profiles if the real interest rate differs from its steadystate value. However, since real interest rates have the same effect on home and foreign consumption growth, relative consumptions still follow a random walk. Eq. (56) is, of course, virtually identical to the central equation of the flexible-price monetary model of exchange rates, despite the presence of sticky prices here. ${ }^{15}$ The only essential difference is that in (56), relative money demand depends on consumption differences, not on output differences as the monetary model supposes. In the present model, the decision to hold money involves an opportunity cost that depends on the marginal utility of consumption. A prediction that money demand depends on consumption or expenditure rather than output is common, however, to many other intertemporal monetary models. ${ }^{16}$

Recognizing that consumption rather than output should enter money demand has potentially important empirical implications, especially in an open economy where intertemporal consumption smoothing typically is easier. For example, transitory output shocks can have permanent exchange rate effects if they induce permanent relative consumption movements. Consider the classic Dornbusch (1976) exercise of an unanticipated permanent rise in

\footnotetext{
${ }^{15}$ See Frenkel (1976) and Mussa (1976) for discussions of the monetary model.

${ }^{16}$ As noted above, Mankiw and Summers (1986) argue that consumption expenditure rather than output should enter empirical money-demand models. They do not, however, emphasize the implications of intertemporal consumption smoothing for financial asset prices or the price level.
} 
the relative home money supply. To see the exchange rate implications of eq. (56), let us first lead it by one period to obtain

$$
\hat{E}^{\prime}=\left(\hat{M}^{\prime}-\hat{M}^{* \prime}\right)-\frac{1}{\sigma \varepsilon}\left(\hat{C}^{\prime}-\hat{C}^{* \prime}\right)
$$

which is simpler than (56) because all variables are constant in the assumed steady state. ${ }^{17}$ Using the above expression to substitute into (56) for $\hat{E}^{\prime}$, and noting that $\hat{C}-\hat{C}^{*}=\hat{C}^{\prime}-\hat{C}^{* \prime}$ by $(55)$ and that $\hat{M}-\hat{M}^{*}=\hat{M}^{\prime}-\hat{M}^{* \prime}$ (since the money-supply shock is permanent), we obtain

$$
\hat{E}=\left(\hat{M}-\hat{M}^{*}\right)-\frac{1}{\sigma \varepsilon}\left(\hat{C}-\hat{C}^{*}\right)
$$

so that $\hat{E}=\hat{E}^{\prime}$. Thus, the exchange rate jumps immediately to its long-run level despite the inability of prices to adjust in the short run. The intuition behind this result is apparent from eq. (56). If consumption differentials and money differentials are both expected to be constant, then agents must expect a constant exchange rate as well.

Indeed, although we have considered only permanent money-supply shocks, the random-walk behavior of consumption differences simplifies the analysis of more general shocks. For more general money-shock processes, the usual forward solution to (56) is just

$$
\hat{E}_{t}=\frac{(1-\beta) \varepsilon}{\beta+(1-\beta) \varepsilon} \sum_{s=t}^{\infty}\left(\frac{\beta}{\beta+(1-\beta) \varepsilon}\right)^{s-t}\left(\hat{M}_{s}-\hat{M}_{s}^{*}\right)-\frac{1}{\sigma \varepsilon}\left(\hat{C}-\hat{C}^{*}\right)
$$

The general result here is that the exchange rate jumps immediately to the flexible-price path corresponding to the new permanent international consumption differential. This doesn't mean, of course, that the model behaves exactly like a flexible-price model: in a flexible-price model there would be no consumption effect. Here, in contrast, the exchange-rate change and the consumption effect are jointly determined.

\subsubsection{A graphical solution for the exchange rate}

A simple diagram (figure 1) illustrates this interdependence for permanent money shocks. The MM schedule graphs eq. (57), which shows how relative

\footnotetext{
${ }^{17}$ Implicitly, we are assuming away speculative exchange-rate bubbles.
} 


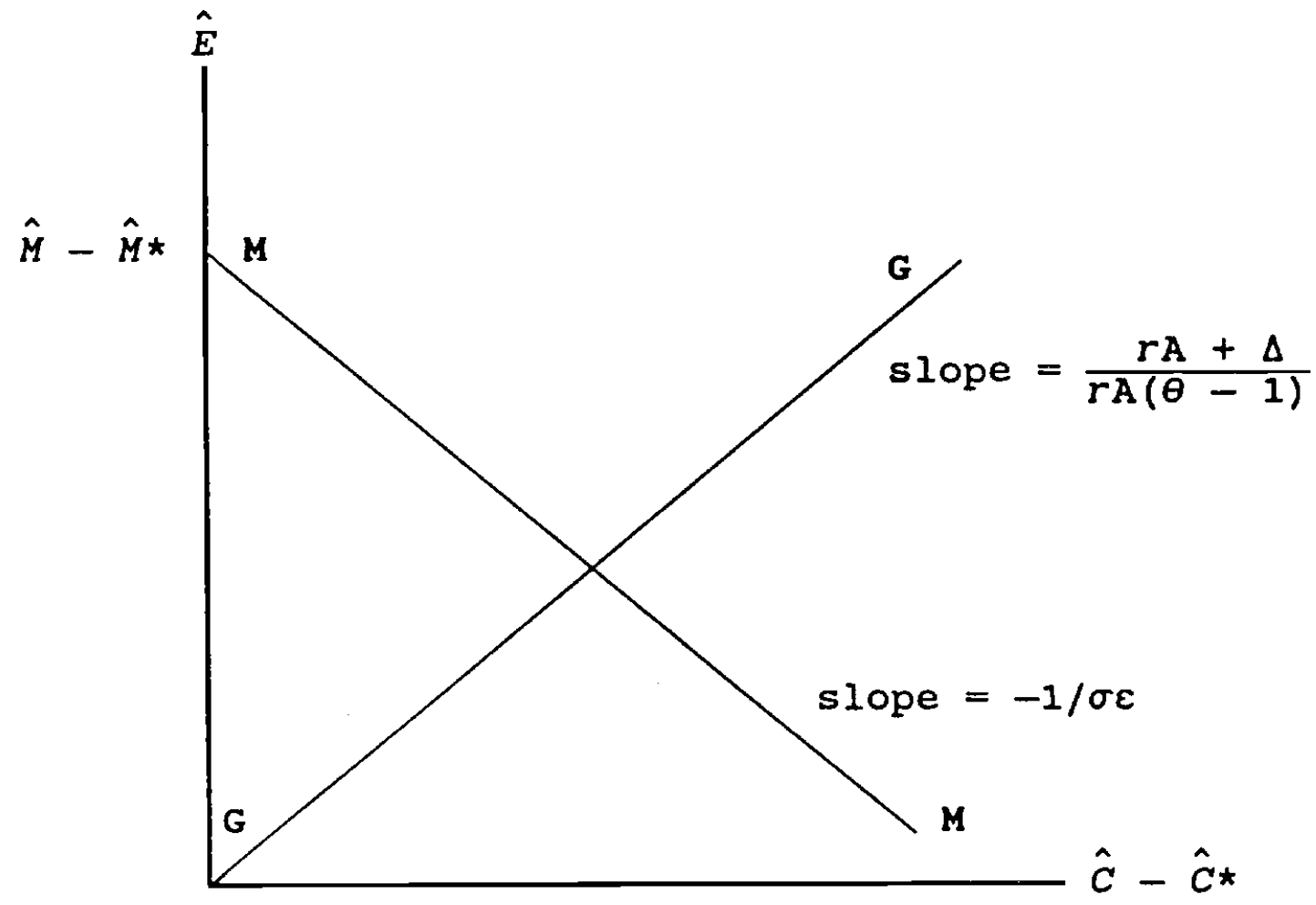

Figure 1

A permanent unanticipated home money-supply increase 
consumption changes affect the exchange rate by changing relative money demand. (Remember that the consumption Euler equations are built into MM .) The schedule's vertical intercept is $\hat{M}-\hat{M}^{*}$, and it slopes downward because relative domestic money demand rises as relative domestic consumption rises.

A second schedule in $\hat{E}$ and $\hat{C}-\hat{C}^{*}$ is derived by using the current-account eqs. (53) and (54) together with the long-run consumption eqs. (37) and (38) to write the long-run consumption difference as

$$
\hat{C}^{\prime}-\hat{C}^{* \prime}=\frac{r \mathrm{~A}}{\Delta}\left[\left(\hat{y}-\hat{y}^{*}\right)-\left(\hat{C}-\hat{C}^{*}\right)-\hat{E}\right]
$$

Eqs. (51) and (52) show that domestic output rises relative to foreign output as the domestic currency depreciates and makes domestic products cheaper in the short run:

$$
\hat{y}-\hat{y}^{*}=\theta \hat{E}
$$

Combining the last two equations with the relative Euler eq. (55), we arrive at the GG schedule:

$$
\hat{E}=\frac{r \mathrm{~A}+\Delta}{r \mathrm{~A}(\theta-1)}\left(\hat{C}-\hat{C}^{*}\right)
$$

This relationship shows the domestic currency depreciation needed to raise relative home output enough to justify a given permanent rise in relative home consumption; it therefore is upward sloping.

The intersection of $\mathbf{M M}$ and $\mathbf{G G}$ is the short-run equilibrium. The domestic currency depreciates, but by an amount proportionally smaller than the increase in the relative home money supply. Since $\hat{E}=\hat{E}^{\prime}$, this is true in the long run as well. ${ }^{18}$

The exchange rate rises less than the relative domestic money supply because, as figure 1 also shows, domestic relative consumption must rise. With nominal prices fixed in the short run, the initial currency depreciation

\footnotetext{
${ }^{18}$ Figure 1 presents an interesting parallel with the textbook diagram of the MundellFleming model that places the exchange rate on the vertical axis and output on the horizontal axis. See, for example, Dornbusch (1980) or Krugman and Obstfeld (1994). The MM schedule is analogous to the Mundell-Fleming model's LM schedule, while GG is analogous to its IS schedule. The similarity between this model's results and those of the Mundell-Fleming model is, however, superficial and partial, as we discuss below.
} 
switches world demand toward domestic products and causes a short run rise in relative domestic income. ${ }^{19}$ Home residents save part of this increased revenue: by running a current-account surplus, they can smooth the increase in their relative consumption over the future.

The exchange-rate effect is smaller the less monopoly power producers have, that is, the larger is the price elasticity of demand, $\theta$. As $\theta \rightarrow \infty$ and a perfectly competitive economy is approached, GG becomes horizontal and the exchange-rate effects of monetary changes disappear. If domestic and foreign goods are perfect substitutes in demand and their nominal prices are fixed, there is no scope for an exchange-rate change. ${ }^{20}$

This diagrammatic analysis extends easily to the case of temporary money shocks. The MM eq. (57) is replaced by (58) while the GG equation continues to hold for the initial period. Thus, the MM schedule's slope is unchanged but its intercept is the discounted sum of future monetary changes from (58). The effects of a temporary money-supply shock on both the exchange rate and current account are smaller than those of a permanent shock. The level of $\hat{C}-\hat{C}^{*}$ determined by the diagram is still permanent, but eq. (58) must be used to calculate the exchange rate's path after the initial, sticky-price period.

\subsubsection{The current account, the terms of trade, and world interest rates}

More can be learned by algebraically solving the model, as we illustrate using the example of a permanent money shock. Together, (57) and (59) imply that the exchange-rate change is

$$
\hat{E}=\frac{(r \mathrm{~A}+\Delta) \sigma \varepsilon}{r \mathrm{~A}(\theta-1)+(r \mathrm{~A}+\Delta) \sigma \varepsilon}\left(\hat{M}-\hat{M}^{*}\right) \leq \hat{M}-\hat{M}^{*}
$$

and the relative consumption change is

$$
\hat{C}-\hat{C}^{*}=\frac{r \mathrm{~A}(\theta-1) \sigma \varepsilon}{r \mathrm{~A}(\theta-1)+(r \mathrm{~A}+\Delta) \sigma \varepsilon}\left(\hat{M}-\hat{M}^{*}\right)
$$

${ }^{19}$ The increase in relative domestic real income is $\hat{y}-\hat{y}^{*}-\hat{E}=(\theta-1) \hat{E}>0$. Because demand has been assumed to be relatively elastic $(\theta>1)$, a country's revenue rises when it sells more due to a fall in its products' prices.

${ }^{20}$ Stockman and Ohanian (1993) highlight this possibility in a model in which perfect competition always obtains. 
To find the equilibrium current account, we combine (37) and (38) to solve for $\hat{C}^{\prime}-\hat{C}^{* \prime}$ as a function of $d F^{\prime} / Q_{0}$, then note that $\hat{C}-\hat{C}^{*}=\hat{C}^{\prime}-\hat{C}^{* \prime}$ by (55), and, finally, use eq. (61) to obtain

$$
\frac{d F^{\prime}}{\mathrm{Q}_{0}}=\frac{(1-n)(\theta-1) \Delta \sigma \varepsilon}{r \mathrm{~A}(\theta-1)+(r \mathrm{~A}+\Delta) \sigma \varepsilon}\left(\hat{M}-\hat{M}^{*}\right)
$$

We see from eq. (62) that the larger the home country (the greater $n$ ), the less the impact of a home money increase on its current account. Armed with $d F^{\prime} / \mathrm{Q}_{0}$, we can solve for all the steady state values. For example, the long-run terms of trade are found by combining (62) with (37), (38), and $(46):^{21}$

$$
\hat{p}(h)^{\prime}-\hat{p}^{*}(f)^{\prime}-\hat{E}^{\prime}=\frac{(\theta-1) \sigma \varepsilon}{r \mathrm{~A}(\theta-1)+(r \mathrm{~A}+\Delta) \sigma \varepsilon}\left(\hat{M}-\hat{M}^{*}\right)
$$

A positive home money shock generates a long-run improvement in the home terms of trade because it leads to an increase in wealth. With higher longrun wealth, home residents substitute out of work into leisure (the opposite happens abroad), leading to a rise in relative home prices. In the short run, of course, domestic goods prices are fixed, and the home terms of trade deteriorate by $\hat{E}$; thus, the short-run and the long-run terms of trade effects go in opposite directions. Intuitively, one would expect the short-run effect to be larger in absolute value, since in the long-run, it is only the interest income on $d F^{\prime} / Q_{0}$ that is driving the substitution from work effort into leisure. Indeed, if one substitutes out for $A$ and $\Delta$ in (60) by using (39) and (43), and compares the result with (63), one sees that the short-run effect must be larger. This does not imply, however, that the long-run terms of trade effect is negligible; it will be large, for example, if $\mu$ is small so that long-run work effort drops sharply with an increase in long-run wealth.

The possibility that money shocks may have long-lasting real effects would seem to be quite general, and not simply an artifact of this particular model. As long as there exists any type of short-run nominal rigidities, unanticipated money shocks are likely to lead to international capital flows. The resulting

\footnotetext{
${ }^{21}$ Note that both the short-run and the long-run terms of trade effects are independent of relative country size. A country's size determines the global impact of its policies, and not their relative (per capita) impact.
} 
transfers will extend the real effects of the shock beyond the initial stickyprice time horizon. In our infinitely-lived agent model with intertemporally separable utility, the real effects are permanent, but in an overlapping generations setting, the effects should still last much longer than, say, the year or two horizon of a typical nominal wage contract.

One can ask whether Dornbusch (1976) type exchange rate overshooting occurs here, although the issue is complicated by the long-run nonneutrality of money. The more interesting question is whether sticky prices lead to more or less exchange rate volatility than one would observe in a world of flexible prices. In fact, in the present model, preset prices actually reduce exchange rate volatility when monetary shocks are predominant. The fact that the inflating country experiences an improvement in its long-run terms of trade tempers the need for initial nominal depreciation. In an appendix we present a model with sticky-price nontraded goods in which a Dornbusch overshooting result can hold. Given the lack of empirical support for the overshooting hypothesis, however, it is unclear that this should be regarded as an essential property of an exchange-rate model. ${ }^{22}$

It is straightforward to solve for the remaining variables in the model. To see how an unanticipated permanent monetary expansion affects the world real interest rate, for example, use the short-run price eqs. (49) and (50) and the long-run eqs. (47) and (48) to express the money-market equilibrium conditions (33) and (34) as

$$
\begin{gathered}
\hat{C}+\frac{\beta}{(1-\beta) \varepsilon} \hat{C}^{\prime}+\sigma\left(\varepsilon+\frac{\beta}{1-\beta}\right)[\hat{M}+(1-n) \hat{E}]=\sigma \beta \hat{r} \\
\hat{C}^{*}+\frac{\beta}{(1-\beta) \varepsilon} \hat{C}^{* \prime}+\sigma\left(\varepsilon+\frac{\beta}{1-\beta}\right)\left(\hat{M}^{*}-n \hat{E}\right)=\sigma \beta \hat{r}
\end{gathered}
$$

Multiply the first of these expressions by $n$, the second by $1-n$, and add. Because, by (37) and (38), $\hat{\mathbf{Q}}^{\prime}=n \hat{C}^{\prime}+(1-n) \hat{C}^{* \prime}=0$ for a pure monetary shock, the consumption Euler eqs. (31) and (32) imply that

$$
\hat{\mathbf{Q}}=n \hat{C}+(1-n) \hat{C}^{*}=-\sigma(1-\beta) \hat{r}
$$

${ }^{22}$ One empirical regularity apparently inconsistent with overshooting is the welldocumented tendency for spot and forward exchange rates to move in tandem. See, for example, Flood (1981). 
and so

$$
\hat{r}=-\left(\varepsilon+\frac{\beta}{1-\beta}\right)\left[n \hat{M}+(1-n) \hat{M}^{*}\right]
$$

A monetary expansion either at home or abroad lowers the world real interest rate in proportion to the increase in the 'world money supply,' $n \hat{M}+$ $(1-n) \hat{M}^{*}$, and, thus, raises global consumption demand. Note that $\varepsilon$ and $\beta$ are the only parameters that enter into (65); parameters such as $\theta$ and $\mu$ wash out because of intertemporal consumption smoothing. The liquidity effect is greater the higher is $\varepsilon$, which is inversely related to the interest-elasticity of money demand. Relatively interest-inelastic money demand (a high value of $\varepsilon)$ means that a monetary expansion will cause a proportionally large decline in the real interest rate. As per eq. (17), there is no effect on the long-run real interest rate, which is tied to the rate of time preference.

What about the nominal interest rate? One can show that monetary expansion in either country lowers nominal interest rates worldwide provided $\varepsilon>1$. (This probably is the empirically relevant case.) A related result holds in the model of the appendix, where the presence of nontraded goods allows home and foreign nominal interest rates to diverge.

While a monetary expansion raises global demand in the short-run by lowering the world real interest rate, it has asymmetric output effects in the two countries if the exchange rate changes. Eqs. (51) and (52) show the short-run output changes. Consider the effects of a unilateral increase in the home money supply. The world real interest rate falls and world demand rises, but because the domestic currency depreciates $(\hat{E}>0)$, some world demand is shifted toward home products at foreign producers' expense. As a result, home output rises relatively more; in fact, foreign output actually can fall.

\subsection{Welfare analysis of international monetary trans- mission}

Domestic monetary expansion can raise or lower output abroad. But output is not a complete measure of welfare. Output is produced only at the expense of effort; moreover, a country's relative output can rise only if its terms of trade worsen. The advantage of our dynamic utility-theoretic approach is that the overall welfare effects of these opposing forces can be rigorously 
evaluated.

We break the problem of evaluating welfare changes into two parts by writing the intertemporal utility function (6) as $U=U^{R}+U^{M}$, where $U^{R}$ consists of the terms depending on consumption and output and $U^{M}$ consists of the terms depending on real money balances.

Consider the change in $U^{R}$ first. Since the economy reaches a steady state after one period, the change in a home resident's lifetime welfare due to consumption and output changes is

$$
d U^{R}=C_{0}^{\frac{\sigma-1}{\sigma}} \hat{C}-\kappa y_{0}^{\mu} \hat{y}+\frac{\beta}{1-\beta}\left(C_{0}^{\frac{\alpha-1}{\sigma}} \hat{C}^{\prime}-\kappa y_{0}^{\mu} \hat{y}^{\prime}\right)
$$

Eq. (20) and the assumption that $C_{0}=y_{0}=\mathrm{Q}_{0}$ show that this equation can be rewritten as

$$
d U^{R}=\mathrm{Q}_{0}^{\frac{\sigma-1}{\sigma}}\left\{\hat{C}-\left(\frac{\theta-1}{\theta}\right) \hat{y}+\frac{\beta}{1-\beta}\left[\hat{C}^{\prime}-\left(\frac{\theta-1}{\theta}\right) \hat{y}^{\prime}\right]\right\}
$$

Eq. (51) shows the value of $\hat{y} ; \hat{C}$ 's value follows from $(60),(61)$, and (64) as

$$
\hat{C}=\frac{(1-n)(\theta-1) r \mathrm{~A}}{r \mathrm{~A}+\Delta} \hat{E}+\hat{\mathbf{Q}}
$$

The long-run home consumption change $\hat{C}^{\prime}$ can be derived from (37), (60), and (62),

$$
\hat{C}^{\prime}=\frac{(1-n)(\theta-1) r \mathrm{~A}}{r \mathrm{~A}+\Delta} \hat{E}
$$

while (44) shows that the long-run home output change is

$$
\hat{y}^{\prime}=-\frac{(1-n)(\theta-1) \theta r}{r A+\Delta} \hat{E}
$$

The corresponding foreign variables are obtained by replacing $1-n$ with $-n$ in the exchange-rate coefficients of these expressions. Thus, all asymmetric effects of the monetary shock are transmitted through the exchange rate.

Returning to (66), we see from the preceding equations and eq. (17) that the impact of the exchange-rate terms on home welfare is zero, leaving

$$
d U^{R}=\frac{\mathbf{Q}_{0}^{\frac{\alpha-1}{\sigma}} \hat{\mathbf{Q}}}{\theta}
$$


This change is the product of the aggregate-demand level change, $d \mathbf{Q}$, and the initial (positive) difference between the marginal utility of consumption and the marginal cost in utility terms of producing consumer goods. The obvious symmetry of the preceding calculation shows that for the foreign country as well,

$$
d U^{* R}=\frac{\mathbf{Q}_{0}^{\frac{\sigma-1}{\sigma}} \hat{\mathbf{Q}}}{\theta}
$$

Thus, the only effect of the money shock on $U^{R}$ and $U^{* R}$ comes from the general increase in world demand in the initial period, and both countries share the benefits equally. This is true despite the permanent increase in home relative consumption caused by the shock.

The fact that unanticipated monetary expansion can raise welfare is familiar from the static closed-economy analyses of Akerlof and Yellen (1985a,b) and Blanchard and Kiyotaki (1987). Because price exceeds marginal cost in a monopolistic equilibrium, aggregate demand policies that coordinate higher work effort move the economy closer to efficient production, with a firstorder impact on welfare. The surprising result in (67) and (68) is that the terms-of-trade and current-account effects that accompany unilateral monetary changes-effects long central to the international policy coordination literature-are of strictly second-order importance here. How can this be?

The crux of the matter is that if home producers lower prices and produce more, they gain revenue but work harder to get it. Starting in the initial equilibrium, where marginal revenue and cost are equal, the utility effects cancel exactly. An unexpected home currency depreciation, which lowers the real price of home goods when prices are sticky, has much the same effect: home producers sell more but work harder too. Foreign producers face the opposite situation. The first-order effect of the monetary expansion thus is to raise global aggregate demand and world output. The associated expenditure-switching effects are only second order. Does the fact that a current-account imbalance arises upset this conclusion? No. Here, at the margin, all effects from reallocating consumption and leisure over time have to be second order as well. ${ }^{23}$

\footnotetext{
${ }^{23}$ Notice that our basic result would hold even with closed international capital markets. Obviously, a crucial underlying assumption is that in the initial situation, producer/workers have equated the marginal disutility of extra effort to the marginal utility of the resulting revenue. This would not necessarily be the case in an economy with initial
} 
Obviously, our result holds in its extreme form only for small monetary expansions. For large shifts, the envelope theorem no longer applies and assessments of welfare outcomes require numerical methods. Nevertheless, our welfare analysis suggests that the possibility of beggar-thy-neighbor currency depreciation has been overemphasized in the academic and policy literature. In their studies of the Great Depression, Eichengreen and Sachs (1985) and Eichengreen (1992) stress that inflationary competitive depreciations led to net increases in world aggregate demand. Our theoretical analysis provides support for their contention that the aggregate-demand benefits were at least as important as the expenditure-switching effects. ${ }^{24}$

Thus far we have not discussed real-balance effects, which affect $U^{M}$ and $U^{* M}$, but these should not reverse our conclusions. Because the marginal utility of money is positive, policies that raise real monetary balances can be Pareto improving. In the case of a unilateral home monetary expansion, home real balances rise in all periods. Foreign real balances, however, rise in the first period but fall in the long run because long-run foreign consumption falls. The net effect abroad is ambiguous. ${ }^{25}$ But unless $\chi$ in (6) is implausibly large, so that real balances have a high weight in total welfare relative to consumption, the aggregate demand effects captured in (67) and (68) are the dominant ones.

\subsection{Government spending shocks}

A government's spending falls on both home and foreign goods, but the taxes that finance it are borne entirely by its own citizens. Their consumption falls, but because they reduce their leisure at the same time, the net effect on world aggregate demand is positive. We have already studied government spending under flexible prices (in section 2.5); now we turn to the sticky-price case, in which the results can be surprisingly different. Again we draw on the loglinearized equations of sections $2.4,2.5$, and 3.1 , abstracting from monetary

involuntary unemployment resulting, say, from efficiency wages. Whether the expenditure switches induced by exchange rates have first-order effects depends, however, on the precise mechanisms generating unemployment.

${ }^{24}$ Embedded in our results is the assumption that initially there is no net iuternational debt. If such debt were present, the fall in the interest rate caused by a monetary expansion would cause a first-order welfare redistribution from the creditor country to the debtor.

${ }^{25}$ It can be shown that for empirically reasonable parameter values, $d U^{* M}>0$. 
changes by assuming $\hat{M}=\hat{M}^{\prime}=\hat{M}^{*}=\hat{M}^{* \prime}=0$.

The solution approach is completely parallel to the one followed in section 3.2. In particular, the MM schedule for this case is still given by eq. (57), but with monetary changes set to zero. Instead of (59), the equation

$$
\hat{E}=\frac{r \mathrm{~A}+\Delta}{r \mathrm{~A}(\theta-1)}\left(\hat{C}-\hat{C}^{*}\right)+\frac{1}{\theta-1}\left[\frac{d G-d G^{*}}{\mathrm{Q}_{0}}+\left(\frac{1}{r}\right) \frac{d G^{\prime}-d G^{* \prime}}{\mathrm{Q}_{0}}\right]
$$

describes the GG schedule. MM now passes through the origin. Although GG has the same positive slope as before, its vertical intercept is proportional to the present discounted value of differential government spending changes. (Recall that $d G$ and $d G^{*}$ are the first-period fiscal shifts while $d G^{\prime}$ and $d G^{* \prime}$ are the shifts in all subsequent periods.)

Figure 2 illustrates a permanent unilateral increase in home government spending (in the case of a temporary change the exchange-rate and relative consumption effects would be muted). Home consumption falls relative to foreign consumption because domestic residents are paying for the government spending. Because this relative consumption change lowers the relative demand for home money, $E$ rises (a depreciation of home currency relative to foreign). ${ }^{26}$ As in our analysis of monetary disturbances above, the exchange rate moves immediately to its new steady state, that is, $\hat{E}=\hat{E}^{\prime}$. This result does not require that the fiscal shock be permanent. Because individuals smooth consumption over time, even temporary fiscal shifts induce a random walk in the exchange rate.

To derive algebraic solutions for the model, one proceeds exactly as in the case of money shocks. (To simplify the resulting expressions we hold $G^{*}$ at zero when this is convenient.) The short-run exchange rate change is

$$
\hat{E}=\frac{r \mathrm{~A}}{r \mathrm{~A}(\theta-1)+(r \mathrm{~A}+\Delta) \sigma \varepsilon}\left[\frac{d G}{\mathrm{Q}_{0}}+\left(\frac{1}{r}\right) \frac{d G^{\prime}}{\mathrm{Q}_{0}}\right]
$$

By eq. (57), $\hat{C}-\hat{C}^{*}=-\sigma \varepsilon \hat{E}$. The current account is given by

$$
\frac{d F^{\prime}}{\mathrm{Q}_{0}}=\frac{(1-n)(\theta-1+\sigma \varepsilon) r \mathrm{~A}}{r \mathrm{~A}(\theta-1)+(r \mathrm{~A}+\Delta) \sigma \varepsilon}\left[\frac{d G}{\mathrm{Q}_{0}}+\left(\frac{1}{r}\right) \frac{d G^{\prime}}{\mathrm{Q}_{0}}\right]-(1-n) \frac{d G}{\mathrm{Q}_{0}}
$$

${ }^{26}$ Remember that in the fiscal-policy experiment we are considering, relative demands for national outputs do not change. 


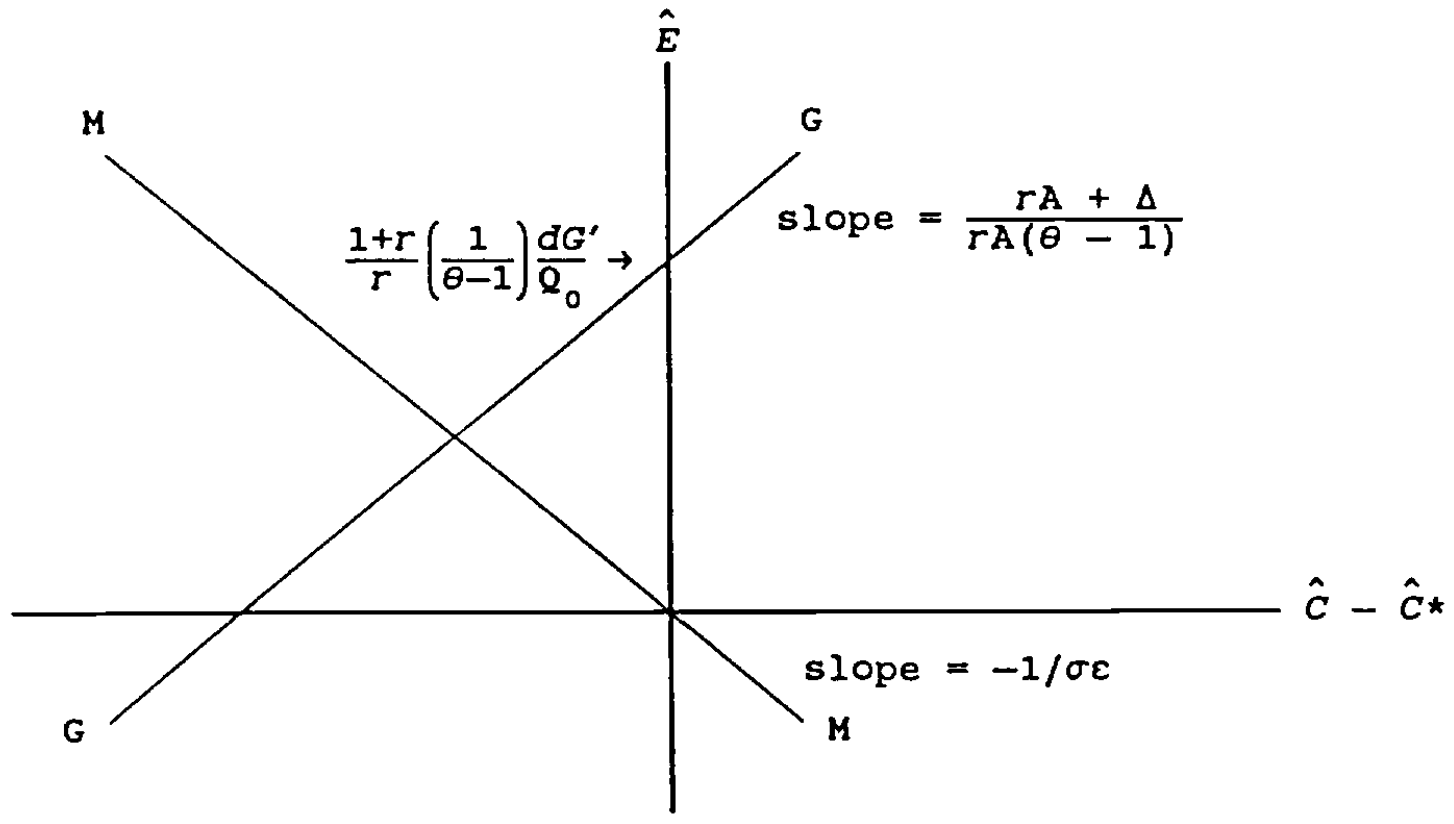

Figure 2

A permanent unanticipated increase in home goverment spending 
In the case of a transitory spending increase $\left(d G^{\prime}=0\right)$, it is clear that the home country runs a current-account deficit. The dominant mechanism is similar to that in flexible-price models: because the tax increase is temporary, consumption falls by less than the rise in government spending. There is a partially offsetting effect here, however, because the home currency depreciation causes a short-run rise in home relative to foreign output. In fact, for a permanent increase in domestic government spending $\left(d G^{\prime}=d G=0\right)$, the home country actually runs a surplus. ${ }^{27}$ The usual result in flexibleprice representative-agent economies is that permanent government spending changes have no current-account effects because they do not tilt the time profile of output net of government expenditure. With sticky prices, however, an unanticipated permanent rise in $G$ tilts the time profile of output.

The effects of government spending on the world real interest rate provide an even more surprising contrast with the flexible-price case. Allowing once again for foreign government spending, one finds the short-run change in the world real interest rate to be

$$
\hat{r}=-\left\{\frac{\mu[\beta+(1-\beta) \varepsilon]}{[1+\sigma(\mu-1)](1-\beta) \varepsilon}\right\}\left[n \frac{d G^{\prime}}{\mathrm{Q}_{0}}+(1-n) \frac{d G^{* \prime}}{\mathrm{Q}_{0}}\right]
$$

The startling implication of eq. (70) is that only innovations in future government spending affect the real interest rate. Current temporary innovations in government spending have no effect. With sticky prices and demanddetermined output, global output rises by the same amount as government spending, so there is no change in the time path of output available for private consumption when the government spending increase is temporary. Eq. (70) also shows that permanently higher government spending temporarily lowers the real interest rate. This contrasts with the textbook flexible-price result of an unchanged interest rate (Barro 1993). Because permanently higher government spending generates a bigger output effect in the short run than in the long run, it results in a declining path of output available for private consumption. These results, which stem from the combination of demanddetermined output in the short run with private consumption smoothing, should not be sensitive to the specific details of our model. ${ }^{28}$

\footnotetext{
${ }^{27}$ This result follows from (69) because $\frac{r}{1+r}>\frac{r A}{r A+\Delta}$.

${ }^{28}$ Our results on the interest-rate effects of fiscal policies, which apply equally to closedand open-economy models, appear to be new.
} 
As was the case for monetary shocks, nominal exchange rates may be less volatile under sticky prices than under flexible prices. A consequence of eqs. (47), (48), and (22) is that the MM equation, $\hat{E}=-\frac{1}{\sigma \varepsilon}\left(\hat{C}-\hat{C}^{*}\right)$, holds in both the sticky-price and flexible-price cases for any fiscal shock (holding money constant). Thus, the exchange-rate impact of fiscal policy is proportional to the induced consumption differential regardless of whether prices are sticky or flexible. But from our preceding discussion of the current account, one can readily confirm that both temporary and permanent fiscal shocks have smaller absolute effects on relative consumption under sticky prices. Hence, the absolute exchange-rate effects are smaller as well.

Obviously, some of the precise positive implications of our model could be changed by allowing for nontraded goods or for home bias in government spending. Our results on interest rates are, however, likely to be relatively robust to such modifications. ${ }^{29}$

An explicit welfare analysis of fiscal policy along the lines of section 3.3 is straightforward. Again, the induced expenditure switching effects are of second-order significance. The major new issue that arises is that the citizens whose government expands foot the entire tax bill for the resulting expansion in world aggregate demand.

Before concluding, we note the absence in this paper of an explicit analysis of productivity shocks. A natural way to portray a productivity shock is as a shift in the parameter $\kappa$ in (6). Finally, standard techniques would easily lead to a stochastic version of the model.

\section{Conclusion}

Our model offers new foundations for thinking about some of the fundamental problems in international finance. Existing models, whether traditional static Keynesian models or newer flexible-price intertemporal models, are too incomplete to offer a satisfactory integrative treatment of exchange rates, output, and the current account. While our model is seemingly quite complex, it yields simple and intuitive insights into the international repercussions of

\footnotetext{
${ }^{29}$ For example, in a version of the model with both traded and nontraded goods, intratemporally separable preferences, and monopolistic competition in both sectors, a permanent change in government spending on tradables still lowers world interest rates, and a temporary change still has no effect.
} 
monetary and fiscal policies. It can be extended in a number of dimensions, including the addition of nontraded goods, pricing to market behavior, home bias in government spending, labor market distortions, and so on.

Although the model leads to some important and novel positive conclusions, we believe its most striking payoff emerges on the normative side. Above, we gave an example in which home monetary expansion benefits foreign residents regardless of its short- and long-run effects on foreign output, the current account, and the terms of trade. Some factors emphasized in Keynesian models of policy transmission turn out, upon closer inspection, to be important individually but largely offsetting taken jointly. This would never be apparent without carefully articulated microfoundations.

In recent historical research, Eichengreen and Sachs question the conventional view that competitive depreciations during the Great Depression were purely counterproductive. They stress that the resulting net increases in aggregate demand may have been at least as important as any expenditureswitching effects: the winners gained more than the losers lost. Our model provides theoretical support for this view by showing how the expenditureswitching effects of unilateral monetary policy expansion can be of secondorder importance for welfare compared with the resulting aggregate demand expansion. Even the supposed victims of 'beggar-thy-neighbor' depreciation may have benefited.

\section{APPENDIX: A MODEL WITH NONTRADED GOODS}

Here we sketch a simple model of a small open economy with nontraded goods in which exchange-rate overshooting is possible. Now, the nontradedgoods sector is monopolistically competitive with preset nominal prices, but there is a single homogeneous tradable good that sells for the same price all over the world. The tradables sector is perfectly competitive and money prices for the tradable are flexible. A home citizen is endowed with a constant quantity of the traded good each period, $y_{T}$, and has a monopoly over production of one of the nontradables $z \in[0,1]$. 
The utility function of the representative producer is

$$
U_{t}=\sum_{s=t}^{\infty} \beta^{s-t}\left[\alpha \log C_{T_{s}}+(1-\alpha) \log C_{N s}+\frac{\chi}{1-\varepsilon}\left(\frac{M_{s}}{P_{s}}\right)^{1-\varepsilon}-\frac{\kappa}{\mu} y_{N s}(z)^{\mu}\right]
$$

where $C_{T}$ is consumption of the traded good and $C_{N}$ is composite nontraded goods consumption, defined by

$$
C_{N}=\left[\int_{0}^{1} c_{N}(z)^{\frac{\theta-1}{\theta}} d z\right]^{\frac{\theta}{\theta-1}}
$$

Here, $P$ is the utility-based price index $P \equiv P_{T}^{\alpha} P_{N}^{1-\alpha} / \alpha^{\alpha}(1-\alpha)^{1-\alpha}$, with $P_{T}=$ $E P_{T}^{*}$ the nominal price of the traded good; $P_{T}^{*}$ is exogenous and constant; and $P_{N}$ is the nontraded goods price index

$$
P_{N}=\left[\int_{0}^{1} p_{N}(z)^{1-\theta} d z\right]^{\frac{1}{1-\theta}}
$$

with $p_{N}(z)$ the money price of good $z$. Bonds are denominated in tradables, and the individual's period budget constraint, with $r$ denoting the constant world interest rate in tradables, is

$$
P_{T t} F_{t}+M_{t}=P_{T t}(1+r) F_{t-1}+M_{t-1}+p_{N t}(z) y_{N t}(z)+P_{T t} y_{T}-P_{N t} C_{N t}-P_{T t} C_{T t}-P_{t} T_{t}
$$

It is convenient to assume that there is no government spending.

In the symmetric market equilibrium, $C_{N t}=y_{N t}(z)$ for all $z$ and domestic residents willingly hold the entire domestic money supply. Thus, for the economy as a whole, the current account is

$$
F_{t}-F_{t-1}=r F_{t-1}+y_{T t}-C_{T t}
$$

We again log-linearize around a steady state in which all exogenous variables are constant and $F_{0}=0$. Consider the effects of an unexpected, permanent increase in the home money supply, $\hat{M}$. Following the same solution approach as in the text, one can show that

$$
\hat{E}=\frac{\beta+(1-\beta) \varepsilon}{\beta+(1-\beta)(1-\alpha+\alpha \varepsilon)} \hat{M}
$$

Here, $\hat{M}$ is the long-run change in the exchange rate-money is neutral in the long run here- because the current account turns out not to change as 
a result of monetary shocks. Notice that if $\varepsilon>1$, the nominal exchange rate overshoots its long-run level. One can understand the role of $\varepsilon$ in overshooting by noting that in this model, $1 / \varepsilon$ is the consumption elasticity of money demand.

\section{References}

[1] Akerlof, George A., and Janet L. Yellen. 'A Near-Rational Model of the Business Cycle, with Wage and Price Inertia.' Quarterly Journal of Economics 100 (Supplement, 1985a): 823-38.

[2] Akerlof, George A., and Janet L. Yellen. 'Can Small Deviations from Rationality Make Significant Differences to Economic Equilibria?' American Economic Review 75 (September 1985b): 708-21.

[3] Ball, Laurence, and David Romer. 'Are Prices Too Sticky?' Quarterly Journal of Economics 104 (August 1989): 507-24.

[4] Barro, Robert J. Macroeconomics, 4th ed. John Wiley \& Sons, 1993.

[5] Blanchard, Olivier J., and Nobuhiro Kiyotaki. 'Monopolistic Competition and the Effects of Aggregate Demand.' American Economic Review 77 (September 1987): 647-66.

[6] Calvo, Guillermo A., and Carlos A.Végh. 'Exchange-Rate Based Stabilisation under Imperfect Credibility.' In Open-Economy Macroeconomics, ed. by Helmut Frisch and Andreas Worgotter. MacMillan, 1993.

[7] Dornbusch, Rudiger. 'Expectations and Exchange Rate Dynamics.' Journal of Political Economy 84 (December 1976): 1161-76.

[8] Dornbusch, Rudiger. Open Economy Macroeconomics. Basic Books, 1980.

[9] Dornbusch, Rudiger. 'Exchange Rates and Prices.' American Economic Review 77 (March 1987): 93-106.

[10] Eichengreen, Barry. Golden Fetters. Oxford University Press, 1992. 
[11] Eichengreen, Barry, and Jeffrey D. Sachs. 'Exchange Rates and Economic Recovery in the 1930s.' Journal of Economic History 45 (December 1985): 925-46.

[12] Fleming, J. Marcus. 'Domestic Financial Policies under Fixed and under Floating Exchange Rates.' International Monetary Fund Staff Papers 9 (November 1962): 369-79.

[13] Flood, Robert P. 'Explanations of Exchange Rate Volatility and Other Empirical Regularities in Some Popular Models of the Exchange Rate Market.' Carnegie-Rochester Conference Series on Public Policy 15 (Autumn 1981).

[14] Frenkel, Jacob A. 'A Monetary Approach to the Exchange Rate: Doctrinal Aspects and Empirical Evidence.' Scandinavian Journal of Economics 78 (May 1976): 200-24.

[15] Frenkel, Jacob A., and Assaf Razin. Fiscal Policies and the World Economy: An Intertemporal Approach. MIT Press, 1987.

[16] Krugman, Paul R. 'Pricing to Market When the Exchange Rate Changes.' In Real-Financial Linkages among Open Economies, ed. by Sven W. Arndt and J. David Richardson. MIT Press, 1987.

[17] Krugman, Paul R., and Maurice Obstfeld. International Economics: Theory and Policy, 3rd ed. HarperCollins, 1994.

[18] McKibbin, Warwick, and Jeffrey D. Sachs. Global Linkages. Brookings Institution, 1991.

[19] Mankiw, N. Gregory. 'Small Menu Costs and Large Business Cycles: A Macroeconomic Model of Monopoly.' Quarterly Journal of Economics 100 (May 1985): 529-39.

[20] Mankiw, N. Gregory. 'Imperfect Competition and the Keynesian Cross.' Economics Letters 26 (1987): 7-14.

[21] Mankiw, N. Gregory, and Lawrence H. Summers. 'Money Demand and the Effects of Fiscal Policies.' Journal of Money, Credit and Banking 18 (November 1986): 415-29. 
[22] Mundell, Robert A. 'Capital Mobility and Stabilization Policy under Fixed and Flexible Exchange Rates.' Canadian Journal of Economics and Political Science 29 (November 1963): 475-85.

[23] Mundell, Robert A. 'A Reply: Capital Mobility and Size.' Canadian Journal of Economics and Political Science 30 (August 1964): 421-31.

[24] Mussa, Michael. 'The Exchange Rate, the Balance of Payments, and Monetary and Fiscal Policy under a Regime of Controlled Floating.' Scandinavian Journal of Economics 78 (May 1976): 229-48.

[25] Mussa, Michael. 'The Theory of Exchange Rate Determination.' In Exchange Rate Theory and Practice, ed. by John F. O. Bilson and Richard C. Marston. University of Chicago Press, 1984.

[26] Obstfeld, Maurice. 'Aggregate Spending and the Terms of Trade: Is There a Laursen-Metzler Effect?' Quarterly Journal of Economics 97 (May 1982): 251-70.

[27] Rogoff, Kenneth. 'Traded Goods Consumption Smoothing and the Random Walk Behavior of the Real Exchange Rate.' Bank of Japan Monetary and Economic Studies 10 (November 1992): 1-29.

[28] Romer, David. 'Openness and Inflation: Theory and Evidence.' Quarterly Journal of Economics 108 (November 1993): 869-903.

[29] Sachs, Jeffrey D. 'The Current Account and Macroeconomic Adjustment in the 1970s.' Brookings Papers on Economic Activity 1 (1981): 201-68.

[30] Startz, Richard. 'Monopolistic Competition as a Foundation for Keynesian Macroeconomic Models.' Quarterly Journal of Economics 104 (November 1989): 737-52.

[31] Stockman, Alan C., and Lee E. Ohanian. 'Short-Run Independence of Monetary Policy under Pegged Exchange Rates and Effects of Money on Exchange Rates and Interest Rates.' Working Paper 4517, National Bureau of Economic Research (November 1993).

[32] Svensson, Lars. E. O., and Sweder van Wijnbergen. 'Excess Capacity, Monopolistic Competition, and International Transmission of Monetary Disturbances.' Economic Journal 99 (September 1989): 785-805. 